\title{
Maternal Socioeconomic Status and Fertility Behaviour in Nigeria: Evidence from a Cross Sectional Nationally Representative Survey
}

\author{
Mary. O. Obiyan, \\ Ambrose Akinlo, \\ Peter O. Ogunjuyigbe, \\ Department of Demography and Social Statistics, \\ Obafemi Awolowo University, Nigeria
}

Doi:10.19044/esj.2019.v15n31p207 URL:http://dx.doi.org/10.19044/esj.2019.v15n31p207

\begin{abstract}
Aims: Studies have linked individual factors such as education and household variables including wealth index as predictors of fertility behaviour. This study aims to examine the effect of socioeconomic characteristics on fertility behaviour when combined as a single proxy among women of reproductive ages in Nigeria. Methods: Data for this study was extracted from the Nigeria Demographic and Health Surveys (NDHS) of 2003, 2008, and 2013. The explanatory variable, "socioeconomic status", was derived as a composite index from the combination of individual and household variables. The outcome variable "fertility behaviour" is measured by total children ever born (CEB). Pearson chi-square test was used to determine the association among variables. Ordinal logistic regression was used to assess the effect of the explanatory variable on the outcome variable. Level of significance was determined at 5\% and 95\% confidence interval. The analysis was carried out using Stata 14.0. Results: There is a statistically significant but inverse association between socioeconomic status and reported CEB. If women were to change their socioeconomic status from low to high, the CEB would reduce by $-0.502(\mathrm{p}<.001)$ and by $-1.038(\mathrm{p}<.000)$. This pattern remained consistent in the adjusted model and across all surveys. Conclusion: The study concludes that women's socioeconomic status significantly predicts fertility behaviour. An improved socioeconomic status would reduce reported CEB. Efforts to reduce fertility in Nigeria must embrace a multi-dimensional approach that creates opportunities aimed at promoting women's economic status.
\end{abstract}

Keywords: Children ever born, fertility behaviour, Nigeria, Ordered Logistic Regression, Socioeconomic Status 


\section{Introduction}

\section{Background}

The fertility level in Nigeria has remained high for decades, with a slight decline in the total fertility rate (TFR) from 6.0 in 1990 to 5.5 in 2013 (National Population Commission \& ICF Macro International, 2014). The country currently ranks as number seven on the list of the ten most populous countries in the world (World Population Review, 2019). Nigeria's population is currently estimated to be about 190 million and projected to exceed 300 million by 2050 , thus, overtaking the USA as the third-largest country in the world, if fertility continues at its current trend (United Nations, 2015). In comparison to other African countries like Ghana (TFR of 4.0), the TFR of Nigeria, at 5.5, remains above the Sub-Saharan Africa TFR average of 5.4 (Mberu \& Reed, 2014).

The country's TFR ranges from 4.3 children per woman in the SouthSouth region to 6.7 in the North-West region; notable variations exist in TFR across the country's six regions (National Population Commission \& ICF Macro International, 2014). With the nation's estimated annual growth rate of $2.60 \%$ and more than $40 \%$ of the population below 14 years, achieving sustainable fertility decline in the nearest decades thus becomes an overreaching goal (Akinyemi \& Isiugo-Abanihe, 2014; IndexMundi, 2018).

Against several interventions and population-related policies aimed at achieving fertility reduction in the country, the goal to achieve a reduction in national population growth rate to $2 \%$ or lower by 2015 , and reduce the TFR by at least 0.6 children every five years by encouraging child spacing through the use of family planning, as stated in the Nigerian government population policy is far from being achieved (NPC, 2004). This indicates the necessity for more targeted interventions to achieve lowered fertility in the country towards the achievement of economic development and the sustainable development goals (Sachs, 2012; Starbird, Norton, \& Marcus, 2016).

High fertility tends to reduce the economic development of a nation as the quality of the population is compromised for quantity (Ushie, 2009; Ushie, Ogaboh, Olumodeji, \& Attah, 2011). In Nigeria, many studies have associated high fertility with factors like early age at marriage (Gayawan \& Adebayo, 2014; Mberu \& Reed, 2014), early age at childbearing (Gayawan \& Adebayo, 2013; Olatoregun, Fagbamigbe, Akinyemi, Oyindamola, \& Bamgboye, 2014), high social values placed on childbearing and son preference (Jegede \& Fayemiwo, 2014; Milazzo, 2014), unmet need for modern contraception and high infant and child mortality rate (Adedini, Odimegwu, Imasiku, \& Ononokpono, 2015; Mekonnen \& Worku, 2011). The adverse outcomes of high fertility include high unemployment rate, scarce or limited economic opportunities, reduced educational opportunities, high poverty rate with more than half the population living on less than two dollars a day, and limited 
availability of health care services, as well as increased infant/child and maternal mortality (Ezeh, Bongaarts, \& Mberu, 2012; Hogan et al., 2010; Mishra \& Smyth, 2010; Ogun, 2010).

In the event of the newly set Sustainable Development Goals by 2030, world leaders and policymakers recognized the importance of education and emphasized its need especially for women as a fundamental tool for empowerment (Bloom, Canning, Fink, \& Finlay, 2009; Costanza, Fioramonti, \& Kubiszewski, 2016). Education enhances decision-making power and aids women to make well-informed and healthy fertility choices (Thévenon, Ali, Adema, \& del Pero, 2012). Also, studies have shown that fertility varies significantly among women with different levels of schooling (Ainsworth, Beegle, \& Nyamete, 1996). A study in Ethiopia established that higher education is associated with smaller number of children (Mekonnen \& Worku, 2011). In Nigeria also, studies have consistently indicated lower fertility among women with secondary and higher levels of education (Adebowale, 2019; Ajala, 2014; Mberu \& Reed, 2014; Solanke, 2015). Thus, a significant increase in women's education at all levels is accompanied by a decline in fertility (National Population Commission \& ICF Macro International, 2014; Ushie et al., 2011).

Another proximate determinant linked with fertility behaviour is the occupational status of a woman (Bick, 2015; Bloom et al., 2009; Kalwij, 2000). A woman's fertility outcome or preference is related to her employment status and the type of job she engages in (Bernhardt, 1993; Bratti, 2003; Kalwij, 2000). The participation of women in the labour force has increased over the years in Nigeria from 56.1\% (2003) to 61.8\% (2013) (National Population Commission \& ICF Macro International, 2014). Another study found that employment opportunities have an impact on fertility behaviour (e.g., sex preference) and levels (Ushie et al., 2011). Women employed in the formal sector have been noted to have fewer children, though, another study associated unemployment with lowered fertility (Babalola \& Akor, 2013). Fertility tends to be lower during periods of unemployment among highly educated women and men, but not among their less-educated counterparts (Kreyenfeld \& Andersson, 2014). While resources are becoming increasingly inadequate to meet household needs, a study found that women want to gain some financial independence before moving into marriage or any other form of commitment (Manning, Trella, Lyons, \& Du Toit, 2010). Increasing proportions of men now look for employed women as partners, thus, reducing marriage chances of unemployed women.

Apart from educational attainment and occupational endeavour, another significant proximate determinant of fertility behaviour is a household's wealth index. Empirical evidence shows clear-cut variations in the fertility levels of women in different wealth quintile (Macro, 2014; Mberu 
\& Reed, 2014). The household wealth index is frequently adopted as a proxy to capture the economic status of individuals or their households. Understanding the income of an individual or household could be difficult due to multiple undisclosed streams of income and other insufficient or misleading information on expenses. Hence, the reason for resorting to the use of wealth index. Studies have also indicated that the socioeconomic and livelihood situation of women contributes to fertility behaviour across many regions (Mberu \& Reed, 2014; Olatoregun et al., 2014).

While previous studies have linked individual socioeconomic characteristics to fertility behaviour, limited studies have examined their influence when combined with derived socioeconomic status (SES) index. This study combined variables at the individual (educational level, work status) and household level (household wealth) to derive a composite variable, i.e., socioeconomic status; and examined its effect on reported CEB of women within reproductive ages $15-49$ in Nigeria.

\section{Methods}

This study utilized the Nigerian Demographic and Health Survey (NDHS) of 2003, 2008, and 2013. The DHS is a nationally representative survey that provides up to date information on the population and health indicators of a country. The 2003 NDHS used two-stage cluster design sampling to select 365 clusters (200 in rural areas and 165 in urban areas) and chose 50 households systematically from each cluster. A total of 7,620 eligible respondents were successfully interviewed. The NDHS 2008 had a total of 888 clusters (286 urban and 602 rural) selected from a complete list of households with an average of 41 households taken from each cluster through equal probability systematic sampling, a total of 33,385 women were interviewed. Lastly, NDHS 2013 used a three-stage stratified sampling design to select a total of 904 clusters (372 urban and 532 rural) with a fixed representative sample of 45 households per cluster and had completed interviews of 38,948 eligible respondents.

In this study, some variables retained the categorization in the NDHS while some others were regrouped. Explanatory variables including work status, household wealth, residence, and regions retained the DHS recodes. Other recoded variables were: age [15-24, 25-34, 35-44, 45+]; educational attainment [none, primary, secondary +]; marital status [not married, married/living together, others], and ideal number of children $[<2,2-4,>4]$.

The key explanatory variable, 'socioeconomic status (SES), is a composite index derived from both individual level [educational attainment, work status] and household level factors [household wealth index]. A composite score was generated from the sum of the three variables. The score ranged from 1-9. Thereafter, this was categorized into low SES (1-3), middle 
SES (4-6), and high SES (7+). The outcome variable in this study is fertility behaviour measured by the variable - 'total children ever born'. The count variable was further grouped into three ordered - <2, 2-3, 4+ categories.

The study analysed the women recode file of the NDHS 2003, 2008, and 2013. The datasets are the three most recent NDHS datasets available in the country. The three surveys were analysed to examine patterns and variations in reported fertility behaviour of women by their socioeconomic status over a period of 11 years. The analysis was carried out at univariate, bivariate, and multivariate level. The descriptive analysis reported the percentages and the bivariate employed Pearson chi-square test to assess the association between outcome and explanatory variables. Using ordinal logistic regression, the multivariate analysis guided by two models examined the relationship between socioeconomic status and reported CEB. Ordinal logistic regression is often used when the response variable is ordinal in nature (Bender \& Grouven, 1997; Das \& Rahman, 2011). The first unadjusted model regressed CEB on SES, while the second model adjusted for selected background characteristics including fertility preference measured by ideal number of children. The coefficients were estimated at $5 \%$ level of statistical significance and 95\% confidence interval (CI). All estimates were weighted appropriately as stipulated for DHS surveys. The analysis was carried out using Stata version 14.0.

\section{Results}

A total of 79,518 women were included in the analysis: 7,598 - 2003, $32,972-2008$, and 38,948 - 2013. Table 1 shows information on the selected background characteristics of respondents. The mean age of respondents was 28.0 years in 2003, 28.7 years in 2008, and 28.9 years in 2013. Women with no education had the highest proportion in 2003 (41.5\%), while those with secondary and higher education were more in 2008 (44.6\%) and 2013 (44.9\%). Overall, across the surveys, approximately six of every ten women were working $(60.3 \%)$. Similarly, over six out of ten women resided in a rural area (61.2\%). Also, most of the respondents were from the North-West region (27.5\%). Respondents who were married or living together with a partner constituted $71.0 \%$ and those from the richest wealth quintile households were $22.9 \%$. Women who reported having less than two children $(40.9 \%)$ and whose ideal number of children were more than four $(70.9 \%)$ had the highest proportion in all surveys.

The distribution of fertility of women by selected background characteristics is shown in Table 2. High CEB was prevalent among older women compared to women of younger ages with p-value $<0.000$ across all surveys. Educational attainment was significantly associated with reported CEB. Women with none or primary education had increased CEB compared 
to those with secondary or more education $(\mathrm{p}<0.000)$. Work status, household wealth, marital status, place of residence, and region of residence were all significant predictors of reported CEB among women aged 15-49 years across the three surveys. A very high proportion of women who reported 2-4 children as ideal reported CEB of below 2 children in 2003 (67.9.0\%, p<0.001), 2008 $(63.5 \%, \mathrm{p}<0.001)$, and 2013 (62.3\%, p<0.001). Further, the socioeconomic status of women strongly predicted reported CEB $(\mathrm{p}<0.000)$. More women with middle socioeconomic status reported CEB of 2-3 children compared to those with low socioeconomic status in 2003. This pattern remained in 2008 and 2013. The higher the socioeconomic status of women, the lower the reported $\mathrm{CEB}$.

Table 3 presents the result of ordinal logistic regression. In the unadjusted model, the results showed that if women were to change their SES from low to high, the CEB would reduce by $-0.502(\mathrm{p}<.001)$ and by -1.038 $(\mathrm{p}<.000)$. This pattern remained across the survey years of 2008 and 2013. In the adjusted model, the ordered log-odds of a decreased CEB only remained if SES were to change from low to high while the other variables are held constant in the model for $2003(\beta=-0.524, \mathrm{p}<0.001), 2008(\beta=-0.562$, $\mathrm{p}<.001)$, and $2013(\beta=-0.719, \mathrm{p}<.001)$. Also, age and marital status of women were significantly associated with reported CEB of women in the adjusted model in all the survey years. For every unit increase in age, the ordered logodds of CEB would increase when the other variables in the model are held constant.

In 2003, if women were to change their region of residence from northcentral to north-east, the ordered logit for CEB would increase by 0.217 , $\mathrm{p}<.041$ while other variables in the model were held constant. In 2008, residing in the north-east $(\beta=0.253, p<.000)$ and north-west $(\beta=0.142$, $\mathrm{p}<.013)$ would increase the probability of an increased CEB, while residing in the south-east $(\beta=-0.155, p<.031)$ and south-west $(\beta=-0.143, p<.023)$ would reduce the ordered log-odds for a high CEB when other variables are held constant. In 2008, while a change in residence from north-central to northwest would result in increased CEB $(\beta=0.149, \mathrm{p}<.003)$, women who changed residence from north-central to south-east would have reported low $\mathrm{CEB}$ ( $\beta=$ $-0.177, \mathrm{p}<.013)$.

A change in ideal number of children from under 2 to between 2 and 4 would reduce the ordered log-odds of a high CEB when other variables in the model are held constant, with a significant association in 2008 ( $\beta=-0.604$, $\mathrm{p}<.000)$ and $2013(\beta=-1.035, \mathrm{p}<.0001)$. 
Table 1. Selected background characteristics of Women aged 15-49 years (2003 - 2013)

Variable $2003(7,598) \quad 2008(32,972) \quad 2013(38,948) \quad$ Total Frequency $(\%) \quad$ Frequency

Frequency

$(79,518)$

$(\%)$

$(\%)$

Frequency

$(\%)$

\begin{tabular}{|c|c|c|c|c|}
\hline Age & $\begin{array}{l}\text { mean age }= \\
28.03\end{array}$ & $\begin{array}{l}\text { mean age }= \\
28.65\end{array}$ & $\begin{array}{l}\text { mean age }= \\
28.86\end{array}$ & \\
\hline $15-24$ & $3,196(42.0)$ & $12,450(37.8)$ & $14,576(37.4)$ & $30,222(38.0)$ \\
\hline $25-34$ & $2,320(30.5)$ & $10,834(32.9)$ & $12,612(32.4)$ & $25,766(32.4)$ \\
\hline $35-44$ & $1,500(19.8)$ & $6,863(20.8)$ & $8,338(21.4)$ & $16,702(21.0)$ \\
\hline $45+$ & $582(7.7)$ & $2,825(8.5)$ & $3,422(8.8)$ & $6,829(8.6)$ \\
\hline \multicolumn{5}{|l|}{$\begin{array}{l}\text { Educational } \\
\text { Attainment }\end{array}$} \\
\hline None & $3,156(41.5)$ & $11,741(35.6)$ & $14,729(37.8)$ & $29,626(37.3)$ \\
\hline Primary & $1,625(21.4)$ & $6,512(19.8)$ & $6,734(17.3)$ & $14,870(18.7)$ \\
\hline Secondary + & $2,817(37.1)$ & $14,719(44.6)$ & $17,485(44.9)$ & $35,022(44.0)$ \\
\hline \multicolumn{5}{|c|}{ Currently Working } \\
\hline No & $3,322(43.7)$ & $13,324(40.4)$ & $14,888(38.2)$ & 31,535 (39.7) \\
\hline Yes & $4,276(56.3)$ & $19,648(59.6)$ & $24,060(61.8)$ & $47,984(60.3)$ \\
\hline \multicolumn{5}{|l|}{ Household Wealth } \\
\hline Poorest & $1,407(18.5)$ & $6,089(18.5)$ & $7,132(18.3)$ & $14,628(18.4)$ \\
\hline Poorer & $1,431(18.8)$ & $6,157(18.7)$ & $7,428(19.1)$ & 15,015 (18.9) \\
\hline Middle & $1,511(19.9)$ & $6,273(19.0)$ & $7,486(19.2)$ & $15,271(19.2)$ \\
\hline Richer & $1,523(20.0)$ & $6,858(20.8)$ & $7,992(20.5)$ & $16,373(20.6)$ \\
\hline Richest & $1,726(22.7)$ & $7,595(23.0)$ & $8,910(22.9)$ & $18,230(22.9)$ \\
\hline \multicolumn{5}{|l|}{ Marital Status } \\
\hline Not married & $1,922(25.3)$ & $8,292(25.2)$ & $9,326(23.9)$ & $19,540(24.6)$ \\
\hline $\begin{array}{l}\text { Married / Living } \\
\text { together }\end{array}$ & $5,318(70.0)$ & $23,280(70.6)$ & $27,830(71.5)$ & $56,427(71.0)$ \\
\hline Others & $357(4.7)$ & $1,400(4.2)$ & $1,793(4.6)$ & $3,551(4.4)$ \\
\hline \multicolumn{5}{|l|}{ Residence } \\
\hline Urban & $2,622(34.5)$ & $11,788(35.8)$ & $16,414(42.1)$ & $30,825(38.8)$ \\
\hline Rural & $4,975(65.5)$ & $21,184(64.2)$ & $22,534(57.9)$ & $48,693(61.2)$ \\
\hline \multicolumn{5}{|l|}{ Regions } \\
\hline North-Central & $1,119(14.7)$ & $4,677(14.2)$ & $5,572(14.3)$ & $\begin{array}{l}11,368.6 \\
(14.3)\end{array}$ \\
\hline North-East & $1,359(17.9)$ & $4,212(12.8)$ & $5,766(14.8)$ & $11,337(14.3)$ \\
\hline North-West & $2,086(27.5)$ & 7,887 (23.9) & $11,877(30.5)$ & $21,850(27.5)$ \\
\hline South-East & 735 (9.7) & $4,042(12.3)$ & $4,476(11.5)$ & $9,254(11.6)$ \\
\hline South-South & $1,341(17.6)$ & $5,417(16.4)$ & $4,942(12.7)$ & $11,699(14.7)$ \\
\hline South-West & $958(12.6)$ & $6,737(20.4)$ & $6,314(16.2)$ & $14,010(17.6)$ \\
\hline \multicolumn{5}{|l|}{ CEB } \\
\hline$<2$ & $3,324(43.8)$ & $13,454(40.8)$ & $15,752(40.4)$ & $32,530(40.9)$ \\
\hline $2-3$ & $1,366(18.0)$ & $6,880(20.9)$ & $8,072(20.7)$ & $16,318(20.5)$ \\
\hline $4+$ & $2,908(38.2)$ & $12,638(38.3)$ & $15,123(38.8)$ & $30,670(38.6)$ \\
\hline \multicolumn{5}{|c|}{ Ideal No of children } \\
\hline$<2$ & $10(0.1)$ & $600(1.8)$ & $299(0.8)$ & $909(1.1)$ \\
\hline $2-4$ & $1,835(24.1)$ & $9,438(28.6)$ & $10,958(28.1)$ & $22,231(28.0)$ \\
\hline$>4$ & $5,753(75.7)$ & $22,934(69.6)$ & $27,691(71.1)$ & $56,378(70.9)$ \\
\hline
\end{tabular}


Table 2. Association between Women's Characteristics and Fertility (2003-2013)

\begin{tabular}{|c|c|c|c|c|c|c|c|c|c|c|c|c|}
\hline \multirow{3}{*}{ Characteristics } & \multicolumn{4}{|c|}{$2003(\mathrm{n}=7,598)$} & \multicolumn{4}{|c|}{$2008(\mathrm{n}=32,972)$} & \multicolumn{4}{|c|}{$2013(\mathrm{n}=38,948)$} \\
\hline & \multicolumn{3}{|c|}{ CEB } & \multirow[t]{2}{*}{$\mathrm{p}$-value } & \multicolumn{3}{|c|}{ CEB } & \multirow[t]{2}{*}{ p-value } & \multicolumn{3}{|c|}{ CEB } & \multirow[t]{2}{*}{ p-value } \\
\hline & $<2$ & $2-3$ & $4+$ & & $<2$ & $2-3$ & $4+$ & & $<2$ & $2-3$ & $4+$ & \\
\hline \multicolumn{13}{|l|}{ Age } \\
\hline $15-24$ & 81.8 & 15.3 & 2.9 & \multirow{4}{*}{$\mathrm{p}<0.000$} & 80.0 & 17.0 & 3.1 & \multirow{4}{*}{$\mathrm{p}<0.000$} & 81.0 & 16.9 & 2.1 & \multirow{4}{*}{$\mathrm{p}<0.000$} \\
\hline $25-34$ & 24.0 & 28.6 & 47.4 & & 26.2 & 32.1 & 41.7 & & 24.7 & 31.6 & 43.7 & \\
\hline $35-44$ & 7.6 & 11.5 & 80.9 & & 7.4 & 15.3 & 77.3 & & 7.9 & 15.3 & 76.7 & \\
\hline $45+$ & 6.7 & 6.9 & 86.3 & & 5.3 & 8.7 & 86.0 & & 5.0 & 10.4 & 84.6 & \\
\hline \multicolumn{13}{|l|}{$\begin{array}{l}\text { Educational } \\
\text { Attainment }\end{array}$} \\
\hline None & 26.6 & 19.7 & 53.7 & \multirow{3}{*}{$\mathrm{p}<0.000$} & 21.7 & 22.4 & 55.8 & \multirow{3}{*}{$\mathrm{p}<0.000$} & 23.8 & 21.4 & 54.9 & \multirow{3}{*}{$\mathrm{p}<0.000$} \\
\hline Primary & 36.2 & 19.6 & 44.2 & & 26.8 & 22.8 & 50.4 & & 25.7 & 21.3 & 53.1 & \\
\hline Secondary + & 67.3 & 15.1 & 17.6 & & 62.2 & 18.8 & 19.1 & & 60.2 & 20.0 & 19.9 & \\
\hline \multicolumn{13}{|l|}{$\begin{array}{l}\text { Currently } \\
\text { Working }\end{array}$} \\
\hline No & 60.5 & 15.7 & 23.8 & \multirow[b]{2}{*}{$\mathrm{p}<0.000$} & 58.3 & 16.9 & 24.8 & \multirow[b]{2}{*}{$\mathrm{p}<0.000$} & 60.5 & 16.8 & 22.7 & \multirow[b]{2}{*}{$\mathrm{p}<0.000$} \\
\hline Yes & 30.7 & 19.7 & 49.6 & & 29.0 & 23.5 & 47.5 & & 28.0 & 23.2 & 48.8 & \\
\hline \multicolumn{13}{|l|}{$\begin{array}{l}\text { Household } \\
\text { Wealth }\end{array}$} \\
\hline Poorest & 31.9 & 19.4 & 48.7 & & 28.9 & 22.0 & 49.1 & & 27.1 & 20.4 & 52.5 & \\
\hline Poorer & 34.6 & 18.6 & 46.8 & & 30.8 & 21.1 & 48.1 & & 33.7 & 20.4 & 46.0 & \\
\hline Middle & 44.3 & 16.8 & 38.9 & $\mathrm{p}<0.000$ & 39.1 & 19.7 & 41.2 & $\mathrm{p}<0.000$ & 41.0 & 18.9 & 40.1 & $\mathrm{p}<0.000$ \\
\hline Richer & 48.0 & 17.3 & 34.8 & & 48.8 & 19.1 & 32.1 & & 45.0 & 20.3 & 34.7 & \\
\hline Richest & 56.7 & 18.0 & 25.3 & & 52.7 & 22.3 & 25.0 & & 52.2 & 23.2 & 24.6 & \\
\hline Marital Status & & & & & & & & & & & & \\
\hline Not married & 98.9 & 1.0 & 0.1 & & 98.5 & 1.2 & 0.3 & & 98.8 & 1.0 & 0.2 & \\
\hline $\begin{array}{l}\text { Married / } \\
\text { Living together }\end{array}$ & 24.7 & 23.9 & 51.4 & $\mathrm{p}<0.000$ & 21.6 & 27.5 & 50.9 & $\mathrm{p}<0.000$ & 22.2 & 27.0 & 50.8 & $\mathrm{p}<0.000$ \\
\hline Others & 30.9 & 21.9 & 47.2 & & 18.4 & 26.9 & 54.7 & & 20.9 & 25.6 & 53.5 & \\
\hline Residence & & & & & & & & & & & & \\
\hline Urban & 49.5 & 17.4 & 33.1 & & 48.5 & 21.2 & 30.3 & & 47.7 & 20.4 & 31.9 & \\
\hline Rural & 40.7 & 18.3 & 41.0 & $\mathrm{p}<0.000$ & 36.5 & 20.7 & 42.8 & $\mathrm{p}<0.000$ & 35.2 & 21.0 & 43.9 & $\mathrm{p}<0.000$ \\
\hline Regions & & & & & & & & & & & & \\
\hline North-Central & 44.0 & 19.4 & 36.6 & & 40.4 & 21.9 & 37.7 & & 42.2 & 21.8 & 36.0 & \\
\hline North-East & 32.7 & 19.3 & 48.1 & & 30.7 & 20.5 & 48.9 & & 35.2 & 21.8 & 43.1 & \\
\hline North-West & 33.4 & 20.2 & 46.4 & $\mathrm{p}<0.000$ & 28.3 & 22.3 & 49.4 & $\mathrm{p}<0.000$ & 31.8 & 19.7 & 48.5 & $\mathrm{p}<0.000$ \\
\hline South-East & 58.8 & 12.9 & 28.3 & & 53.1 & 14.9 & 32.0 & & 52.9 & 15.7 & 31.4 & \\
\hline South-South & 54.7 & 14.1 & 31.2 & & 50.6 & 19.3 & 30.1 & & 51.1 & 18.8 & 30.1 & \\
\hline South-West & 54.9 & 18.8 & 26.3 & & 46.8 & 23.6 & 29.6 & & 42.8 & 25.8 & 31.4 & \\
\hline $\begin{array}{l}\text { Ideal No of } \\
\text { children }\end{array}$ & & & & & & & & & & & & \\
\hline$<2$ & 60.6 & --- & 39.4 & & 38.4 & 19.3 & 42.4 & & 39.9 & 11.1 & 49.1 & \\
\hline $2-4$ & 67.9 & 16.0 & 16.1 & $\mathrm{p}<0.001$ & 63.5 & 21.7 & 14.8 & $\mathrm{p}<0.001$ & 62.3 & 22.3 & 15.4 & $\mathrm{p}<0.001$ \\
\hline$>4$ & 36.0 & 18.6 & 45.4 & & 31.5 & 20.6 & 47.9 & & 31.8 & 20.2 & 48.0 & \\
\hline
\end{tabular}

Association between Women's Socioeconomic Status and Fertility

Socioeconomic

Status

\begin{tabular}{|c|c|c|c|c|c|c|c|c|c|c|c|c|}
\hline Low & 31.6 & 20.1 & 48.3 & & 26.3 & 22.4 & 51.3 & & 27.7 & 21.3 & 51.0 & \\
\hline Middle & 45.9 & 15.6 & 38.5 & $\mathrm{p}<0.000$ & 43.3 & 18.6 & 38.1 & $\mathrm{p}<0.000$ & 43.1 & 17.9 & 39.0 & $\mathrm{p}<0.000$ \\
\hline High & 57.1 & 18.8 & 24.2 & & 53.6 & 22.0 & 24.4 & & 51.0 & 23.5 & 25.5 & \\
\hline
\end{tabular}


Table 3. Ordered logit models for fertility behaviour of Women by socioeconomic status and individual characteristics (2003-2013)

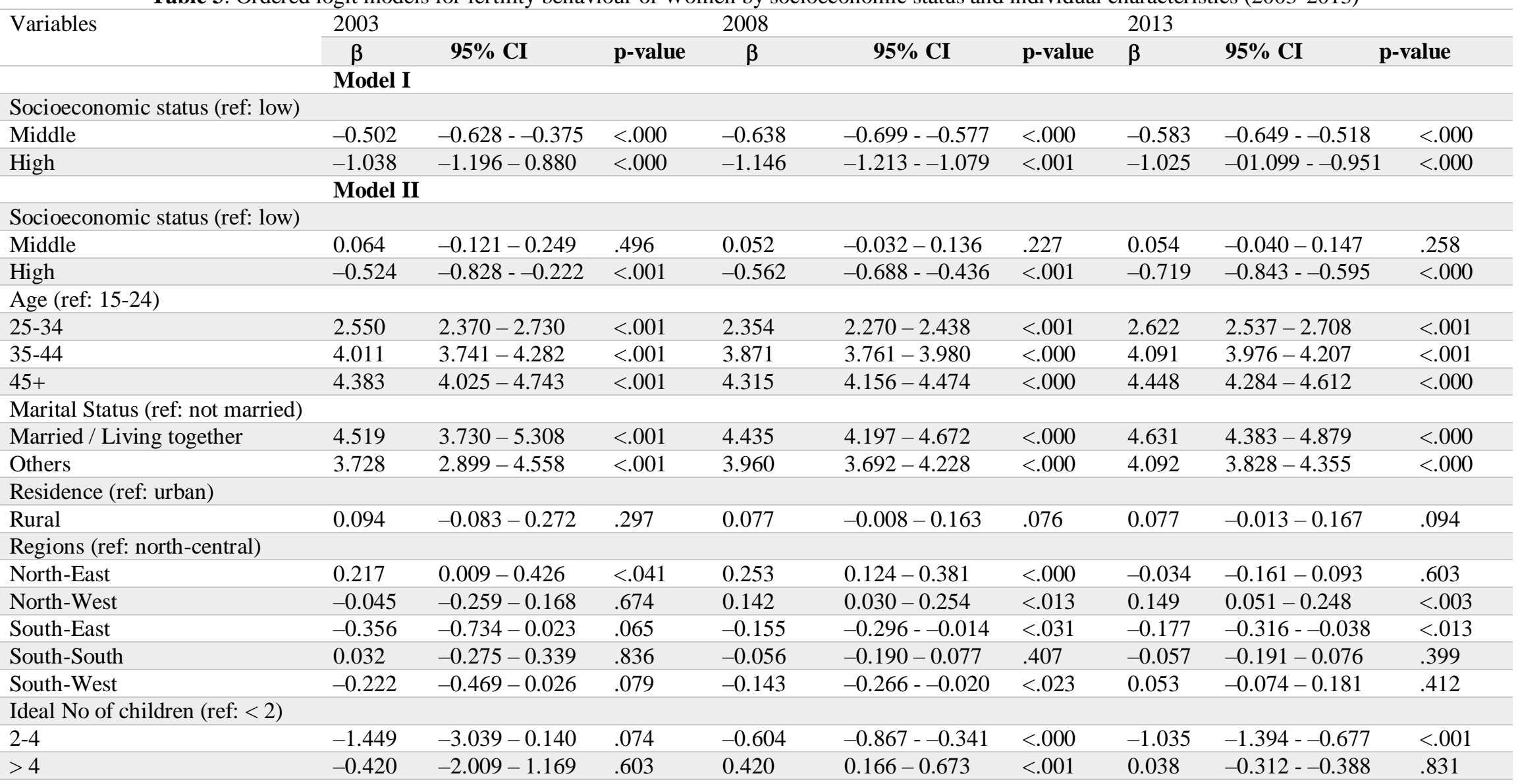




\section{Discussion}

This study examined the effect of socioeconomic status on fertility behaviour among women aged 15-49 years using ordinal logistic regression. The study found a significant association between reported CEB and women SES. Lower fertility was associated with increased SES. This finding is consistent with an earlier study which found that an improvement in socioeconomic status is vital to achieving fertility reduction (Williams et al., 2013). Likewise, when selected background characteristics were controlled, the pattern found was similar to the unadjusted model whereby a change in SES from low to high would reduce reported CEB. As found in this study, earlier studies have also established that socioeconomic characteristics act as underlying determinants of fertility behaviour (Adhikari, 2010; Okezie, Ogbe, \& Okezie, 2010).

The index - SES - used in this study was derived from a combination of individual (education, work status) and household (household wealth quintile) variables. Educational attainment of a woman is synonymous to her fertility. Previous studies showed that educated mothers will more likely have lower births and well-spaced births than uneducated mothers implying higher infant and child survival (Askew, Maggwa, \& Obare, 2017; Basu, 2002; Ndahindwa et al., 2014). Also found in this study and corroborated by existing evidence is a significant association between work status and reported CEB as working women tend towards lower fertility compared to non-working women (Mishra \& Smyth, 2010).

Working women would more likely be autonomous in making decisions that affect their reproductive outcomes such as the use of modern contraceptives, delayed age at first marriage, and age at first birth as childrearing reduces the time available for work and clashes with personal aspirations (Mishra \& Smyth, 2010; Patidar, 2018). Another study also reported that factors such as age at marriage, age at first conception, level of education, and employment status were directly associated with fertility behaviour. On the other hand, the indirect factors include religion, ethnicity, husband's education and occupation, place of residence, employment opportunities in the modern sector, and household wealth (Adhikari, 2010; Okezie et al., 2010).

The findings of the study demonstrated that wealthier women reported having a lesser number of children compared to those who are poor (Askew et al., 2017). This finding is consistent with other studies, which established that women who have high SES are often more educated. Thus, they will likely participate more in labour force, as well as have more negotiating power in the household to adopt family planning methods thereby reducing unplanned pregnancies (Adebowale, Gbadebo, \& Afolabi, 2016; Adhikari, 2010; Porter \& King, 2012; Takyi, 1993). Two of the seventeen sustainable development 
goals aim to provide quality education,(Goal 4) and achieve gender equality (Goal 5) (Kumar, Kumar, \& Vivekadhish, 2016). Increased access to education and decent work especially for women and girls is a tool for a sustainable economy. Increased participation of women especially in formal jobs reduces the gender inequality gap and promotes economic growth and development. Women who are educated would make better informed decisions regarding their health and that of their family (Obiyan \& Kumar, 2015; Soetan \& Obiyan, 2019; Solanke, Amoo, \& Idowu, 2018).

As expected, the age of women and marital status were significant predictors of fertility in the study. Older women reported higher CEB compared to those in younger ages because the former gradually tended towards completed fertility. Currently married women or those living together with a partner had higher fertility compared to others due to increased exposure to intercourse, conception, and childbearing. Further, this study highlights existing differentials in the fertility of women across the geopolitical zones in the country. Women in the south were more likely to report lower fertility than those in the north (Adebowale, 2019; Solanke, 2015). Some of the factors attributed to this included early age at marriage, low educational attainment, and low autonomy of women (Ayo, Adeniyi, \& Ayodeji, 2016; Soetan \& Obiyan, 2019).

Recent demographic indicators of the country showed that about 89 dependents per 100 working-age adults and $44 \%$ of the population are aged under 15 years, which implies fertility will keep booming even if TFR is to reduce from its current average rate of 5.7 children per woman. The cost of high fertility and rapid population growth in the country is huge. These put further pressure on the limited resources and deepen poverty among the population. It is obvious that high fertility in the country would make achieving the national population policy of 2004 to reduce TFR to become unachievable. Hence, Nigeria needs urgent steps to curb the rapid population growth.

\section{Conclusion}

This study has contributed to the ongoing discourse on fertility and its determinants in Nigeria. It further reiterated that socioeconomic status (SES) of a woman is a strong predictor of fertility. The higher the socioeconomic status of a woman, the more the likelihood of reduced fertility. High fertility poses several challenges to women, households, and the country. Hence, it becomes important to advocate for policies that enhance the economic status of women. While debates have been ongoing as to how to achieve lowered fertility in many African nations including Nigeria, this study proposes a multidimensional and contextual approach to attain this. First, programs that will create or increase educational and employment opportunities to improve 
the socioeconomic status of women should be encouraged. Second, this study calls for the development and implementation of policies that abolish early age at marriage in the country. Third, regulating fertility should become a priority especially through indirect approaches such as encouraging girl-child education in all regions of the country. Other effective strategies that would change people's mindset in the country towards a low ideal family size should be embarked upon.

\section{Conflict of Interest}

The authors declare none.

\section{References:}

1. Adebowale, A. S. (2019). Ethnic Disparities in Fertility and its Determinants in Nigeria. Fertility research and practice, 5(1), 3.

2. Adebowale, A. S., Gbadebo, B., \& Afolabi, F. R. (2016). Wealth Index, Empowerment and Modern Contraceptive Use among Married Women in Nigeria: Are they interrelated? Journal of Public Health, 24(5), 415-426.

3. Adedini, S. A., Odimegwu, C., Imasiku, E. N., \& Ononokpono, D. N. (2015). Unmet Need for Family Planning: Implication for Under-Five Mortality in Nigeria. Journal of health, population, and nutrition, 33(1), 187.

4. Adhikari, R. (2010). Demographic, Socio-Economic, and Cultural Factors affecting Fertility Differentials in Nepal. BMC pregnancy and childbirth, 10(1), 1.

5. Ainsworth, M., Beegle, K., \& Nyamete, A. (1996). The Impact of Women's Schooling on Fertility and Contraceptive Use: A Study of Fourteen Sub-Aaharan African Countries. The World Bank Economic Review, 10(1), 85-122.

6. Ajala, A. O. (2014). Factors associated with Teenage Pregnancy and Fertility in Nigeria. Children, 5(2).

7. Akinyemi, A. I. \& Isiugo-Abanihe, U. C. (2014). Demographic dynamics and development in nigeria. Etude de la Population Africaine, 27(2), 239.

8. Askew, I., Maggwa, N., \& Obare, F. (2017). Fertility Transitions in Ghana and Kenya: Trends, Determinants, and Implications for Policy and Programs. Population and Development Review, 43, 289-307.

9. Ayo, A. S., Adeniyi, F. F., \& Ayodeji, A. M. (2016). Regional differences in Adolescent Childbearing in Nigeria. Journal of Population and Social Studies [JPSS], 24(2), 101-116.

10. Babalola, S. J. \& Akor, M. (2013). An Empirical Analysis of Labour Force Participation of Married Women in Adamawa State, Nigeria. 
Journal of Emerging Trends in Economics and Management Sciences, 4(1), 1 .

11. Basu, A. M. (2002). Why does education lead to lower fertility? A Critical Review of some of the Possibilities. World Development, 30(10), 1779-1790.

12. Bender, R. \& Grouven, U. (1997). Ordinal Logistic Regression in Medical Research. Journal of the Royal College of physicians of London, 31(5), 546.

13. Bernhardt, E. M. (1993). Fertility and Employment. European sociological review, 9(1), 25-42.

14. Bick, A. (2015). The Quantitative Role of Child Care for Female Labor Force Participation and Fertility. Journal of the European Economic Association.

15. Bloom, D. E., Canning, D., Fink, G., \& Finlay, J. E. (2009). Fertility, Female labor Force Participation, and the Demographic Dividend. Journal of Economic Growth, 14(2), 79-101.

16. Bratti, M. (2003). Labour Force Participation and Marital Fertility of Italian Women: The Role of Education. Journal of Population economics, 16(3), 525-554.

17. Costanza, R., Fioramonti, L., \& Kubiszewski, I. (2016). The Un Sustainable Development Goals and the Dynamics of Well-Being. Frontiers in Ecology and the Environment, 14(2), 59-59.

18. Das, S. \& Rahman, R. M. (2011). Application of Ordinal Logistic Regression Analysis in Determining Risk Factors of Child Malnutrition in Bangladesh. Nutrition journal, 10(1), 124.

19. Ezeh, A. C., Bongaarts, J., \& Mberu, B. (2012). Global Population Trends and Policy Options. The Lancet, 380(9837), 142-148.

20. Gayawan, E. \& Adebayo, S. B. (2013). A Bayesian Semiparametric Multilevel Survival Modelling of Age at First BIrth in Nigeria. Demographic Research, 28, 1339-1372.

21. Gayawan, E. \& Adebayo, S. B. (2014). Spatial Pattern and Determinants of Age at Marriage in Nigeria Using a Geo-Additive Survival Model. Mathematical Population Studies, 21(2), 112-124.

22. Hogan, M. C., Foreman, K. J., Naghavi, M., Ahn, S. Y., Wang, M., Makela, S. M., . . . Murray, C. J. (2010). Maternal Mortality for 181 countries, 1980-2008: A Systematic Analysis of Progress towards Millennium Development Goal 5. The Lancet, 375(9726), 1609-1623.

23. IndexMundi (2018). Nigeria Demographics Profile 2018. Retrieved fromhttps://www.indexmundi.com/nigeria/demographics_profile.htm 1 accessed August 20, 2019

24. Jegede, A. S. \& Fayemiwo, A. S. (2014). Cultural and Ethical Challenges of Assisted Reproductive Technologies in the Management 
of Infertility among the Yoruba of Southwestern Nigeria. African journal of reproductive health, 14(2), 115-127.

25. Kalwij, A. S. (2000). The effects of Female Employment Status on the Presence and Number of Children. Journal of population economics, 13(2), 221-239.

26. Kreyenfeld, M. \& Andersson, G. (2014). Socioeconomic Differences in the Unemployment and Fertility Nexus: Evidence from Denmark and Germany. Advances in life course research, 21, 59-73.

27. Kumar, S., Kumar, N., \& Vivekadhish, S. (2016). Millennium Development goals (mdgs) to Sustainable Development Goals (sdgs): Addressing Unfinished Agenda and Strengthening Sustainable Development and Partnership. Indian journal of community medicine: official publication of Indian Association of Preventive \& Social Medicine, 41(1), 1.

28. Macro, N. P. C. A. I. (2014). Nigeria Demographic and Health Survey 2013. Calverton, Maryland, USA.

29. Manning, W. D., Trella, D., Lyons, H., \& Du Toit, N. C. (2010). Marriageable Women: A Focus on Participants in a Community Healthy Marriage Program. Family relations, 59(1), 87-102.

30. Mberu, B. U. \& Reed, H. E. (2014). Understanding Subgroup Fertility Differentials in Nigeria. Population review, 53(2), 23.

31. Mekonnen, W. \& Worku, A. (2011). Determinants of Fertility in Rural Ethiopia: The Case of Butajira Demographic Surveillance System (dss). BMC public health, 11(1), 782.

32. Milazzo, A. (2014). Son preference, fertility and family structure: Evidence from reproductive behavior among nigerian women. World Bank Policy Research Working Paper(6869).

33. Mishra, V. \& Smyth, R. (2010). Female Labor Force Participation and Total Fertility Rates in the Oecd: New evidence from Panel Cointegration and Granger Causality Testing. Journal of Economics and Business, 62(1), 48-64.

34. National Population Commission \& ICF Macro International (2014). Nigeria Demographic and Health Survey 2013. Nigeria, and Rockville, Maryland, USA: NPC and ICF International.

35. Ndahindwa, V., Kamanzi, C., Semakula, M., Abalikumwe, F., HedtGauthier, B., \& Thomson, D. R. (2014). Determinants of Fertility in Rwanda in the Context of a Fertility Transition: A Secondary analysis of the 2010 Demographic and Health Survey. Reproductive health, $11(1), 87$.

36. NPC (2004). National Economic Empowerment and Development Strategy (needs). Abuja: National Planning Commission. 
37. Obiyan, M. O. \& Kumar, A. (2015). Socioeconomic inequalities in the Use of Maternal Health Care Services in Nigeria: Trends between 1990 and 2008. Sage Open, 5(4), 2158244015614070.

38. Ogun, T. (2010). Infrastructure and Poverty Reduction: Implications for urban development in Nigeria. Paper presented at the Urban Forum.

39. Okezie, C., Ogbe, A., \& Okezie, C. (2010). Socio-economic Determinants of Contraceptive Use among Rural Women in Ikwuano Local Government Area of Abia State, Nigeria. International NGO Journal, 5(4), 74-77.

40. Olatoregun, O., Fagbamigbe, A. F., Akinyemi, O. J., Oyindamola, B., \& Bamgboye, E. A. (2014). A Comparative Analysis of Fertility Differentials in Ghana and Nigeria. African journal of reproductive health, 18(3), 36-47.

41. Patidar, H. (2018). Women's Empowerment and Fertility Behaviour among the Tribals of Rajasthan, India. Space and Culture, India, 5(3), 129-139.

42. Porter, M. \& King, E. M. (2012). Fertility and women's labor force participation in developing countries. Retrieved from Pop/PoV Reaserch Network Conference, Cape Town, South Africa.

43. Sachs, J. D. (2012). From Millennium Development Goals to Sustainable Development Goals. The Lancet, 379(9832), 2206-2211.

44. Soetan, R. O. \& Obiyan, M. O. (2019). Socioeconomic Differentials in Employment Status and Involvement in Household Decision-Making mong Ever-Married Women in Nigeria. Frontiers in Sociology, 4, 49.

45. Solanke, B. L. (2015). Marriage Age, Fertility Behavior, and Women's Empowerment in Nigeria. Sage Open, 5(4), 2158244015617989.

46. Solanke, B. L., Amoo, E. O., \& Idowu, A. E. (2018). Improving Postnatal Checkups for Mothers in West Africa: A multilevel analysis. Women \& health, 58(2), 221-245.

47. Starbird, E., Norton, M., \& Marcus, R. (2016). Investing in family planning: Key to achieving the sustainable development goals. Global health: science and practice, 4(2), 191-210.

48. Takyi, B. K. (1993). TheStatus of Women and Fertility Behavior in Sub-Saharan Africa: The Effects of Female Labor Force Participation and Gender Preferences on Fertility in Ghana.

49. Thévenon, O., Ali, N., Adema, W., \& del Pero, A. S. (2012). Effects of reducing Gender Gaps in Education and Labour Force Participation on eEonomic Growth in the Ooecd.

50. United Nations. (2015). World population projected to reach 9.7 billion by 2050 . Retrieved from https://www.un.org/en/development/desa/news/population/2015report.html accessed August 25, 2019 
51. Ushie, M. (2009). Fertility differentially in urban and rural Nigeria: A Comparative Study of Calabar and Bendi Communities in Cross River State, Nigeria. Unpublished Ph. d Thesis of the University of Calabar, Calabar-Nigeria.

52. Ushie, M., Ogaboh, A. A., Olumodeji, E., \& Attah, F. (2011). Sociocultural and economic determinants of fertility differentials in rural and Urban Cross Rivers state, Nigeria. Journal of Geography and Regional Planning, 4(7), 383.

53. Williams, J., Ibisomi, L., Sartorius, B., Kahn, K., Collinson, M., Tollman, S., \& Garenne, M. (2013). Convergence in fertility of South Africans and Mozambicans in rural South Africa, 1993-2009. Global health action, 6.

54. World Population Review (2019). Total population by Country 2019. Retrieved from http://worldpopulationreview.com/countries/ accessed August 15.2019 